\title{
ASTHMA IMPROVEMENT IN CHILDREN WITH ECZEMA TREATED WITH AZATHIOPRINE: A CASE SERIES
}

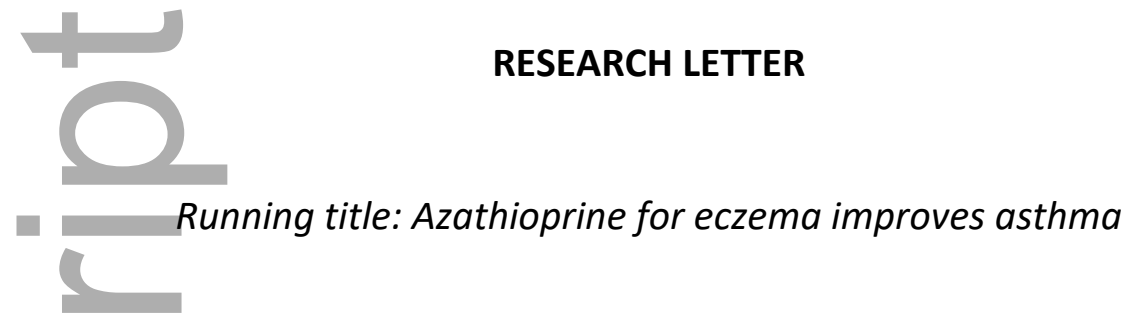

Corresponding and primary author: Dr. Seamus McWhirter

E-mail: seamusmcwhirter@gmail.com

Affiliation: Box Hill Hospital, Eastern Health, 8 Arnold St, Box Hill, 3128, Victoria, Australia.

Contact: +61438191521

ORCID identifier: 0000-0001-6682-3024

Co-authors:

Prof Phil Robinson, Department of Respiratory, The Royal Children's Hospital Flemington, Victoria, Australia

A/Prof David Orchard, Department of Dermatology, The Royal Children's Hospital Flemington, Victoria, Australia.

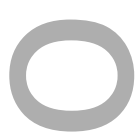

Conflict of Interest: David Orchard is a current AJD Editorial Board Member

The authors received no financial support for the research presented in this article.

Ethical approval of the study was obtained from the affiliated Human Research Ethics Committee (HREC). HREC Reference Number: HREC/61826/RCHM-2020.

This is the author manuscript accepted for publication and has undergone full peer review but has not been through the copyediting, typesetting, pagination and proofreading process, which may lead to differences between this version and the Version of Record. Please cite this article as doi: $10.1111 /$ AJD.13517

This article is protected by copyright. All rights reserved 
Key words: eczema, azathioprine, asthma, child, dermatology

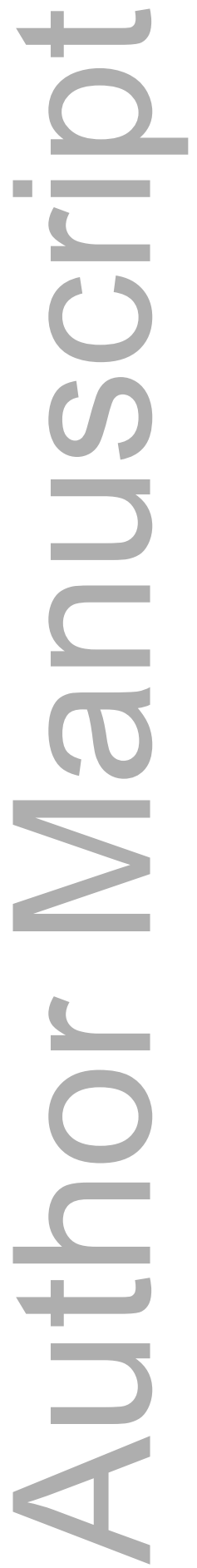

This article is protected by copyright. All rights reserved 
Article type : Research Letter

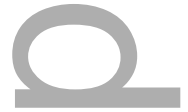

Systemic immunomodulatory agents are frequently prescribed for children with eczema that is unresponsive to topical treatment. The safety of agents such as azathioprine in paediatric populations when used in eczema sufferers is well recognized $^{1}$, however its safety and utility in children with concomitant immunoglobulin E (IgE) related conditions such as asthma is not established.

Both atopic dermatitis and asthma are strongly associated with total and allergenspecific IgE production ${ }^{2-3}$, and hence immunosuppression has remained a pivotal component of treatment for both conditions. Azathioprine, along with oral cyclosporin, methotrexate and mycophenolate mofetil are all reported to be effective in atopic dermatitis ${ }^{4-6}$. For asthma, data does not exist on the efficacy or safety for immunomodulatory agents such as azathioprine in children ${ }^{7}$. Given the high frequency of comorbid allergic asthma in children being treated for their eczema with azathioprine, it is important to investigate the impact that azathioprine has in controlling these same patients' asthma symptoms.

In this case series, medical records were reviewed retrospectively for 12 patients suffering from severe eczema who also suffered with asthma and were treated between 2014 and 2018. Data regarding their asthma disease burden before and after treatment with azathioprine was reviewed to assess its ability to reduce asthma symptoms. Those patients treated in the clinic whom had comorbid asthma had completed six of the seven questions of a validated asthma control questionnaire $^{8}$ (ACQ) as routine care, before and after they had completed treatment with azathioprine. There was no capacity for testing spirometry within the dermatological practice, and hence this was not within the medical records and why this was not completed as part of the ACQ. 
In addition to the questionnaire, information regarding patient demographics, duration of azathioprine, IgE titre, preventer inhaler use before and after azathioprine and any reported side-effects were extracted. Decision to cease azathioprine was related to the clinical response of the patient's eczema. Monitoring, including full blood counts and liver function testing of patients was conducted in line with published guidelines ${ }^{1}$. Consent was obtained from a parent or carer of the child and ethical approval of the study was obtained from the affiliated Human Research Ethics Committee (HREC). HREC Reference Number: HREC/61826/RCHM-2020.

12 children (8M, 4F; mean age 10.16 \pm 2.33 ) were included in the case series (see Table 1). The mean duration of azathioprine therapy was 11.8 months $( \pm 4.47)$. IgE levels (mean $3640.83 \mathrm{IU} / \mathrm{mL}$ ) ranged from 419 to $17679 \mathrm{IU} / \mathrm{mL}$ prior to commencement of azathioprine therapy.

Of the twelve patients, only two had any reported symptoms of asthma upon ceasing the azathioprine (see figure 1). Asthma control questionnaire scores dropped from a mean of 7.5 prior to commencing azathioprine, to 0.9 after their treatment ( $p$ value $<0.05$ ). Six of the seven patients who were using a preventer inhaler therapy prior to commencing azathioprine were able to cease their inhaler. No patients were treated with systemic corticosteroids during this period. One case (Case 6) had four hospital admissions for asthma in the year prior to commencing azathioprine, and after twelve months of azathioprine therapy for her eczema, no longer had any symptoms of asthma and was able to discontinue her preventer therapy. Four patients reported side effects over the duration of treatment, with abdominal pain and gastrointestinal side effects listed most common, none of which were significant enough to warrant cessation. No abnormalities in blood test monitoring were seen in this cohort.

The results presented suggest that azathioprine may be a useful medication in controlling asthma symptoms in children, and this should be considered when prescribing oral immunosuppressive agents for children with severe eczema. 
Being an uncontrolled, retrospective chart analysis, there are other potential reasons to account for the asthma improvement in this cohort. These include factoring in the natural history of asthma within the group and whether the impact of the azathioprine was via settling eczema rather than directly impacting upon asthma pathogenesis. This was also a very allergic cohort with an extremely high average IgE level and improvement may be limited to this setting of high allergy.

While concerns exist regarding the safety of agents such as azathioprine, only mild clinical side effects were reported in this case series, and many studies have now contributed to a consensus that these agents are safe to use in children with the appropriate monitoring. Given a number of children with severe eczema also suffer from asthma, the significant improvement in this group of patients treated with azathioprine is promising and should be considered when deciding which immunosuppressive agent most appropriate.

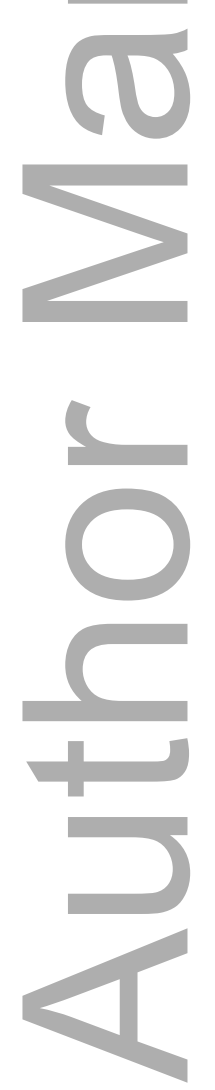

This article is protected by copyright. All rights reserved 


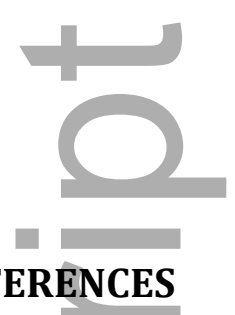

1. Yee J,Orchard D. Monitoring recommendations for oral azathioprine, methotrexate and cyclosporin in a paediatric dermatology clinic and literature review. Australas J Dermatol. 2018;59(1):31-40. https://doi.org/10.1111/ajd.12526

2. Liu FT, Goodarzi H, Chen HY. IgE, mast cells, and eosinophils in atopic dermatitis. Clin Rev Allergy Immunol. 2011;41(3):298-310.

https://doi.org/10.1007/s12016-011-8252-4

3. Sunyer J, Anto JM, Castellsague J et al. Total serum IgE is associated with asthma independently of specific IgE levels. The Spanish Group of the European Study of Asthma. Eur Respir J. 1996;9(9):1880-4.

https://doi.org/10.1183/09031936.96.09091880

4. Notaro ER, Sidbury R. Systemic Agents for Severe Atopic Dermatitis in Children. Paediatr drugs. 2015;17(6):449-57. https://doi.org/10.1007/s40272-015-0150-4

5. Murphy LA, Atherton D. A retrospective evaluation of azathioprine in severe childhood atopic eczema, using thiopurine methyltransferase levels to exclude patients at high risk of myelosuppression. Br J Dermatol. 2002;147(2):308-15. https://doi.org/10.1046/i.1365-2133.2002.04922.x 6. Caufield M, Tom WL. Oral azathioprine for recalcitrant pediatric atopic dermatitis: clinical response and thiopurine monitoring. J Am Acad Dermatol. 2013;68(1):29-35. https://doi.org/10.1016/i.jaad.2012.07.001

7. Bush A, Pedersen S, Hedlin G et al. Pharmacological treatment of severe, therapy-resistant asthma in children: what can we learn from where? Eur Respir J. 2011;38(4):947-58. https://doi.org/10.1183/09031936.00030711 
8. Juniper EF, O'Byrne PM, Guyatt GH et al. Development and validation of a questionnaire to measure asthma control. Eur Respir J. 1999;14(4):902-7. https://doi.org/10.1034/j.1399-3003.1999.14d29.x

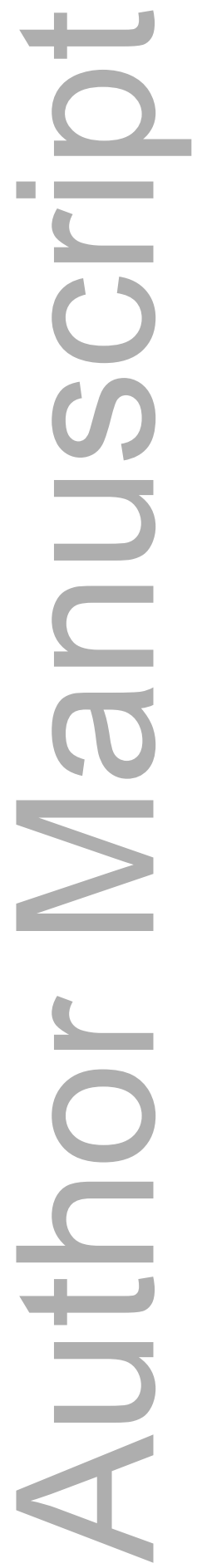

This article is protected by copyright. All rights reserved 
Table 1. Case series of asthma control in 12 patients treated with azathioprine

\begin{tabular}{|c|c|c|c|c|c|c|c|c|c|}
\hline Case & Sex & Age & $\begin{array}{l}\text { IgE } \\
(I U / m L)\end{array}$ & $\begin{array}{l}\text { Duration } \\
\text { azathioprine } \\
\text { (months) }\end{array}$ & $\begin{array}{l}\text { Baseline } \\
\text { ACQ6* }\end{array}$ & $\begin{array}{l}\text { Preventer } \\
\text { inhaler } \\
\text { required } \\
\text { prior } \\
(Y / N)\end{array}$ & $\begin{array}{l}\text { Completion } \\
\text { ACQ6* }\end{array}$ & $\begin{array}{l}\text { Preventer } \\
\text { inhaler } \\
\text { required } \\
\text { following } \\
(\mathrm{Y} / \mathrm{N})\end{array}$ & $\begin{array}{l}\text { Side- } \\
\text { effects }\end{array}$ \\
\hline 1 & $\mathrm{M}$ & 11 & 3412 & 10 & 8 & $\mathrm{Y}$ & 2 & $\mathrm{~N}$ & $\begin{array}{l}\text { Transient } \\
\text { tiredness } \\
\text { and nausea }\end{array}$ \\
\hline 2 & & 9 & 419 & 15 & 12 & Y & 0 & $\mathrm{~N}$ & \\
\hline 3 & & 7 & 17679 & 9 & 5 & $\mathrm{~N}$ & 0 & $\mathrm{~N}$ & \\
\hline 4 & M & 6 & 1670 & 8 & 6 & $\mathrm{~N}$ & 0 & $\mathrm{~N}$ & $\begin{array}{l}\text { Occasional } \\
\text { abdominal } \\
\text { pain }\end{array}$ \\
\hline 5 & & 9 & 1773 & 7 & 5 & Y & 0 & $\mathrm{~N}$ & $\begin{array}{l}\text { Occasional } \\
\text { GIT upset }\end{array}$ \\
\hline 6 & $\mathrm{~F}$ & 11 & 12784 & 12 & 10 & Y & 0 & $\mathrm{~N}$ & \\
\hline 7 & & 12 & 1312 & 8 & 8 & $\mathrm{~N}$ & 0 & $\mathrm{~N}$ & \\
\hline 8 & & 8 & 675 & 10 & 9 & Y & 0 & $\mathrm{~N}$ & \\
\hline 9 & $\mathrm{~F}$ & 12 & 689 & 22 & 19 & Y & 10 & Y & \\
\hline
\end{tabular}

This article is protected by copyright. All rights reserved 


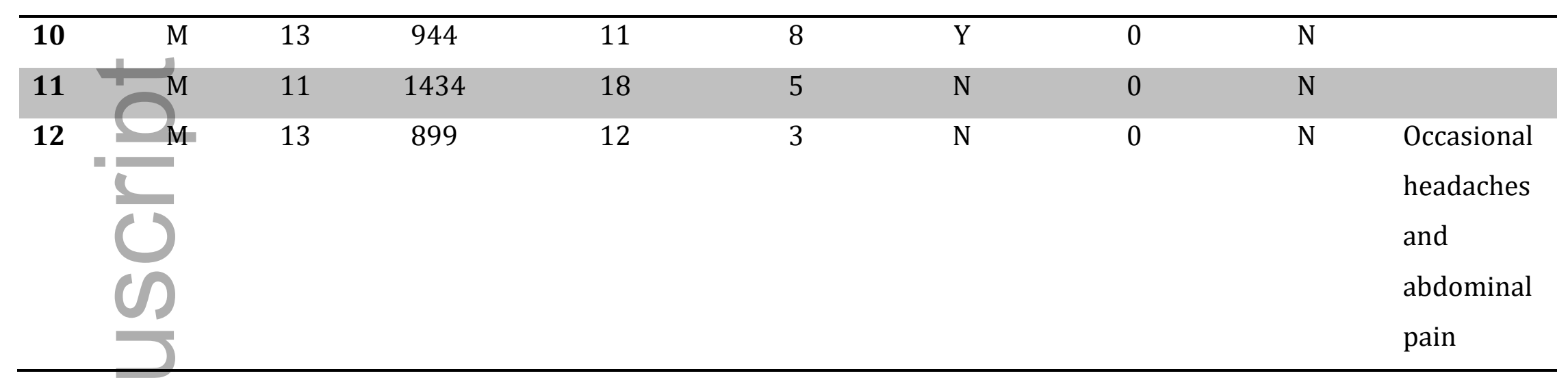

*ACQ6 is from six of the seven questions from the ACQ7 validated tool ${ }^{8}$

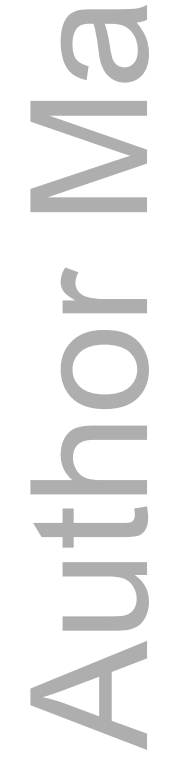

This article is protected by copyright. All rights reserved 


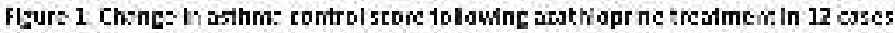

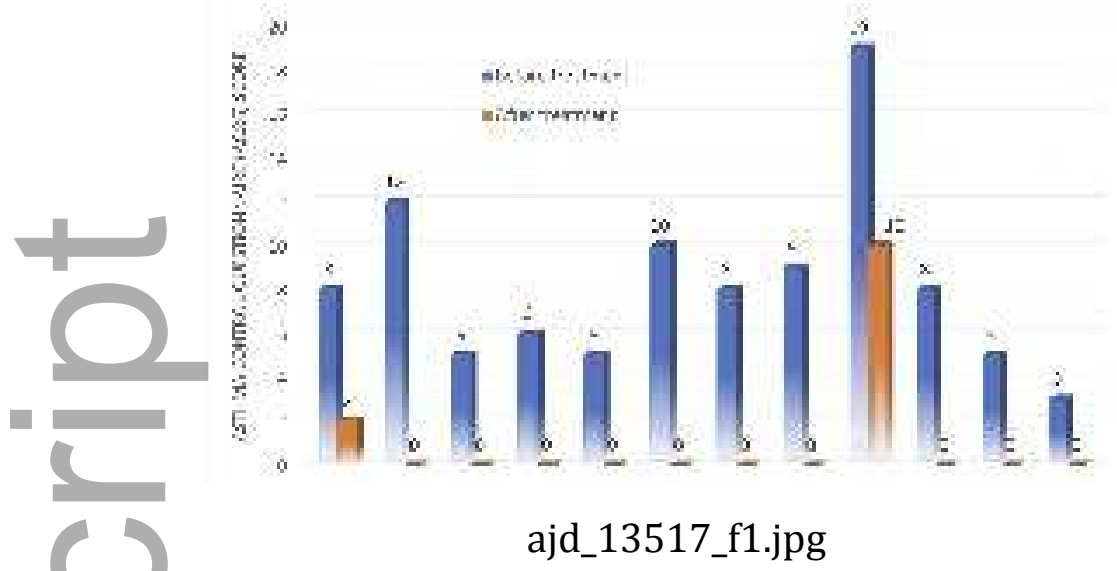

12
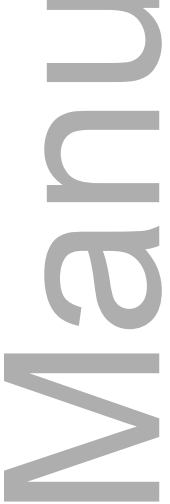

_13517_f1.jpg

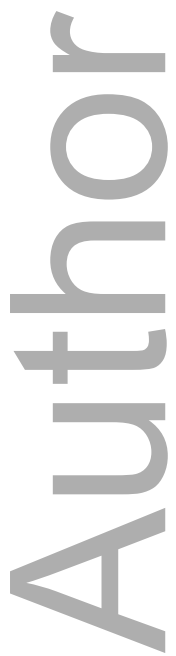




\section{University Library}

\section{- M M I N E R VA A gateway to Melbourne's research publications}

Minerva Access is the Institutional Repository of The University of Melbourne

Author/s:

McWhirter, S;Robinson, P;Orchard, D

Title:

Asthma improvement in children with eczema treated with azathioprine: A case series.

Date:

2021-05

Citation:

McWhirter, S., Robinson, P. \& Orchard, D. (2021). Asthma improvement in children with eczema treated with azathioprine: A case series.. Australas J Dermatol, 62 (2), pp.e306e308. https://doi.org/10.1111/ajd.13517.

Persistent Link:

http://hdl.handle.net/11343/276659 